\title{
Preparation of novel blue phosphate pigments in imitation of turquoise
}

\section{(Preparação de novos pigmentos azuis de fosfato imitando turquesa)}

\author{
H.Onoda ${ }^{*}$, R.Sasaki \\ ${ }^{1}$ Kyoto Prefectural University, Department of Informatics and Environmental Sciences, 1-5, Shimogamo \\ Nakaragi-cyo, Sakyo-ku, Kyoto 606-8522, Japan
}

\begin{abstract}
As a novel blue pigment, various hydrated copper aluminum phosphate imitating turquoise, $\mathrm{CuAl}_{6}\left(\mathrm{PO}_{4}\right)_{4}(\mathrm{OH})_{8} \cdot 4 \mathrm{H}_{2} \mathrm{O}$, were prepared by mixing copper nitrate solution, aluminum nitrate solution, phosphoric acid, and sodium hydroxide solution. Samples with similar chemical composition with turquoise were prepared. The obtained powders were evaluated with X-ray diffraction, infrared spectra, ultraviolet-visible reflectance spectra, and $\mathrm{L}^{*} \mathrm{a}^{*} \mathrm{~b}^{*}$ color space. Further, other related compositions were also investigated. Samples heated at low temperature were light blue powder. By heating at $700{ }^{\circ} \mathrm{C}$, the color of materials changed to deep green. Samples with high copper ratio indicated lower $\mathrm{L}^{*}$ value and small $\mathrm{a}^{*}$ and $\mathrm{b}^{*}$ values. The low copper ratio was suitable to obtain light blue and deep green phosphate pigments.
\end{abstract}

Keywords: phosphate pigment, turquoise, color.

\section{Resumo}

Como novo pigmento azul, vários fosfatos hidratados de cobre e alumínio imitando turquesa, $\mathrm{CuAl}_{6}\left(\mathrm{PO}_{4}\right)_{4}(\mathrm{OH})_{8} .4 \mathrm{H}_{2} \mathrm{O}$, foram preparados misturando solução de nitrato de cobre, solução de nitrato de alumínio, ácido fosfórico e solução de hidróxido de sódio. Amostras com composição química semelhante à turquesa foram preparadas. Os pós obtidos foram avaliados com difração de raios $X$, espectros de infravermelho, espectros de refletância no ultravioleta-visível e espaço de cores $L^{*} a^{*} b^{*}$. Além disso, outras composições relacionadas também foram investigadas. Amostras aquecidas a baixas temperaturas resultaram em pós de cor azul claro. Ao aquecer a $700^{\circ} \mathrm{C}$, a cor dos materiais mudou para verde intenso. Amostras com alta proporção de cobre indicaram menor valor de $L^{*}$ e pequenos valores de $a^{*} e b^{*}$. A baixa proporção de cobre foi adequada para obter pigmentos de fosfato azul claro e verde escuro.

Palavras-chave: pigmento fosfato, turquesa, cor.

\section{INTRODUCTION}

Recently, the use of harmful metals has been restricted in the world. However, because suitable substitutes have not been obtained, some materials containing harmful metals have been used in many fields [1-4]. For example, the inorganic color pigments containing metals such as mercury, cadmium, and lead have some merits, including high light stability, heat-resistant coloring visibility, cost, etc. [5-7]. In addition, because the oxide pigments have low coloring and covering, they are difficult to use for paints and plastics [8]. The sulfate and nitrate pigments have a lower heat resistance than oxide pigments and require harmful and/or combustible gas to synthesize. Furthermore, it is difficult to prepare the sulfide and nitrate pigments with repeatability $[9,10]$. Therefore, the novel inorganic pigments are required with suitable properties and without difficult production methods $[11,12]$.

There are some kinds of inorganic blue pigments that are

*h-onoda@kpu.ac.jp

Dhttps://orcid.org/0000-0001-6267-2783 available for use, for example, Prussian blue, mixed metal oxide, cobalt blue, cerulean, cobalt-chromium blue, and so on [13-16]. Some of these pigments also include harmful metals. Therefore, novel blue pigment without harmful and precious metals is required. We focus on the natural ore, turquoise, $\mathrm{CuAl}_{6}\left(\mathrm{PO}_{4}\right)_{4}(\mathrm{OH})_{8} \cdot 4 \mathrm{H}_{2} \mathrm{O}$, because this ore includes no harmful and precious metals [17, 18]. Natural ores have high light stability and heat resistance. Because of their solidity, they are expected to have applications for plastics, paint, ceramics, and so on.

In a previous study, we prepared novel inorganic pigments imitating turquoise, $\mathrm{CuAl}_{6}\left(\mathrm{PO}_{4}\right)_{4}(\mathrm{OH})_{8} \cdot 4 \mathrm{H}_{2} \mathrm{O}$, from copper oxide, aluminum hydroxide, and phosphoric acid by heating [19]. The obtained materials had the $\mathrm{X}$-ray diffraction (XRD) peaks of $\mathrm{CuAl}_{6}\left(\mathrm{PO}_{4}\right)_{4}(\mathrm{OH})_{8} \cdot 4 \mathrm{H}_{2} \mathrm{O}$ and $\mathrm{CuO}$. However, the color of samples was dark, therefore, a different process is required to prepare the novel blue inorganic pigments. In this study, novel inorganic pigments imitating turquoise were synthesized by mixing copper nitrate solution, aluminum hydroxide or nitrate solution, phosphoric acid, and sodium hydroxide solution, and then heated to repress their solubility. The obtained materials were estimated from the viewpoint of pigment. 


\section{EXPERIMENTAL}

Target material
$\mathrm{CuAl}_{6}\left(\mathrm{PO}_{4}\right)_{4}(\mathrm{OH})_{8} \cdot 4 \mathrm{H}_{2} \mathrm{O}$, was
reaction:
$\mathrm{Cu}\left(\mathrm{NO}_{3}\right)_{2}+6 \mathrm{Al}\left(\mathrm{NO}_{3}\right)_{3}+4 \mathrm{H}_{3} \mathrm{PO}_{4}+8 \mathrm{NaOH}+4 \mathrm{H}_{2} \mathrm{O} \rightarrow$
$\mathrm{CuAl}_{6}\left(\mathrm{PO}_{4}\right)_{4}(\mathrm{OH})_{8} \cdot 4 \mathrm{H}_{2} \mathrm{O}+8 \mathrm{NaNO}_{3}+12 \mathrm{HNO}_{3}$

$0.5 \mathrm{~mol} / \mathrm{L}$ copper and aluminum solutions were prepared from copper nitrate and aluminum nitrate in the ratio of $\mathrm{Cu} / \mathrm{Al}=1 / 6$. Then, a $0.5 \mathrm{~mol} / \mathrm{L}$ phosphoric acid $(28 \mathrm{~mL})$ was added to these copper and aluminum mixed solutions in the ratio of $\mathrm{Cu} / \mathrm{Al} / \mathrm{P}=1 / 6 / 4$ (turquoise ratio). The mixed solutions were adjusted to $\mathrm{pH} 5,7$, and 9 with an $8 \mathrm{~mol} / \mathrm{L}$ sodium hydroxide solution. The precipitates were filtered and then dried. A part of precipitates was heated to 300, 500, and $700{ }^{\circ} \mathrm{C}$ for $1 \mathrm{~h}$ under air condition. Other compositions with molar ratios of $\mathrm{Al} / \mathrm{P}=3 / 2$ and $\mathrm{Cu} / \mathrm{Al}=1 / 3,1 / 2$, and $2 / 3$ were also studied using the same method. The chemical equations were as follows:

$$
\begin{aligned}
& \mathrm{Cu}\left(\mathrm{NO}_{3}\right)_{2}+3 \mathrm{Al}\left(\mathrm{NO}_{3}\right)_{3}+2 \mathrm{H}_{3} \mathrm{PO}_{4}+5 \mathrm{NaOH} \rightarrow \\
& \mathrm{CuAl}_{3}\left(\mathrm{PO}_{4}\right)_{2}(\mathrm{OH})_{5}+5 \mathrm{NaNO}_{3}+6 \mathrm{HNO}_{3} \\
& 3 \mathrm{Cu}\left(\mathrm{NO}_{3}\right)_{2}+6 \mathrm{Al}\left(\mathrm{NO}_{3}\right)_{3}+4 \mathrm{H}_{3} \mathrm{PO}_{4}+12 \mathrm{NaOH} \rightarrow \\
& \mathrm{Cu}_{3} \mathrm{Al}_{6}\left(\mathrm{PO}_{4}\right)_{4}(\mathrm{OH})_{12}+12 \mathrm{NaNO}_{3}+12 \mathrm{HNO}_{3} \\
& 2 \mathrm{Cu}\left(\mathrm{NO}_{3}\right)_{2}+3 \mathrm{Al}\left(\mathrm{NO}_{3}\right)_{3}+2 \mathrm{H}_{3} \mathrm{PO}_{4}+7 \mathrm{NaOH} \rightarrow \\
& \mathrm{Cu}_{2} \mathrm{Al}_{3}\left(\mathrm{PO}_{4}\right)_{2}(\mathrm{OH})_{7}+7 \mathrm{NaNO}_{3}+6 \mathrm{HNO}_{3}
\end{aligned}
$$

These samples were prepared at $\mathrm{pH} 7$ with sodium hydroxide solution. All chemicals were of commercial purity (Wako Chemical Ind., Osaka, Japan) and were used without further purification. The crystal and binding compositions of these materials were analyzed using X-ray diffraction (XRD) and infrared (IR) spectroscopy. The XRD patterns were recorded in an X-ray diffractometer (MiniFlex, Rigaku, Akishima, Japan) using monochromatic $\mathrm{CuK} \alpha$ radiation. IR spectra of samples were recorded with a spectrometer (FTIR 720, Horiba, Kyoto, Japan) using the KBr disk method. The color of phosphate pigments was estimated from the ultraviolet-visible (UV-vis) reflectance spectra (UV2100, Shimadzu, Kyoto, Japan; reference compound: $\left.\mathrm{BaSO}_{4}\right)$. The color of the pigments was also estimated with a color analyzer (TES135 Plus, TES Electrical Electronic, Taipei, Taiwan). The $\mathrm{L}^{*}$ value means the lightness of powder, in which 100 is white and, on the opposite side, 0 is black. The $a^{*}$ value means the redness of materials, with positive (maximum +128$)$ and negative (-128) values corresponding with red and green, respectively [20]. The $b^{*}$ value indicates the yellowish, in which positive (maximum +128$)$ and negative $(-128)$ values correspond with yellow and blue, respectively.

\section{RESULTS AND DISCUSSION}

Composition of $\mathrm{CuAl}_{6}\left(\mathrm{PO}_{4}\right)_{4}(\mathrm{OH})_{8} \cdot 4 \mathrm{H}_{2} \mathrm{O}$ : Fig. $1 \mathrm{~A}$ shows
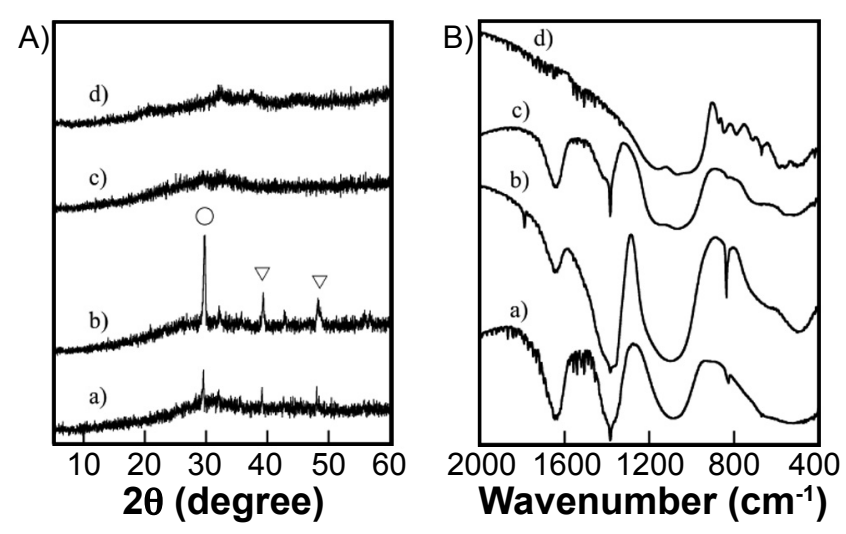

Figure 1: XRD patterns (A) and IR spectra (B) of samples with turquoise composition $(\mathrm{Cu} / \mathrm{Al}=1 / 6)$ heated at various temperatures (pH 5): a) R.T.; b) $300{ }^{\circ} \mathrm{C}$; c) $500{ }^{\circ} \mathrm{C}$; and d) $700{ }^{\circ} \mathrm{C} . \mathrm{O}_{-}$ $\mathrm{CuAl}_{6}\left(\mathrm{PO}_{4}\right)_{4}(\mathrm{OH})_{8} \cdot 4 \mathrm{H}_{2} \mathrm{O} ; \nabla-\mathrm{CuO}$.

[Figura 1: Padrões de DRX (A) e espectros de FTIR (B) de amostras com composição de turquesa $(\mathrm{Cu} / \mathrm{Al}=1 / 6)$ aquecidas a várias temperaturas ( $\mathrm{pH}$ 5): a) temperatura ambiente; b) $300{ }^{\circ} \mathrm{C}$; c) $500{ }^{\circ} \mathrm{C} ;$ e d) $\left.700{ }^{\circ} \mathrm{C}.\right]$

the XRD patterns of the samples synthesized at various conditions. The sample prepared at room temperature (R.T.) indicated weak peaks of turquoise and copper oxide. These peaks became strong by heating at $300{ }^{\circ} \mathrm{C}$. On the other hand, samples heated at 500 and $700{ }^{\circ} \mathrm{C}$ were in the amorphous state. This was related to the weakness of turquoise for heating because its composition includes hydroxide anion and crystalline water. Fig. 1B shows the IR spectra of the samples synthesized at various temperatures. The absorption at about $1150 \mathrm{~cm}^{-1}$ was due to turquoise ore [21]. The peaks at 1385 and $1630 \mathrm{~cm}^{-1}$ were caused by nitrate anion and water, respectively [22]. Because all samples had other absorption peaks, they were the mixture of turquoise and other compounds.

Fig. 2 shows the photographs of the samples heated at various temperatures. Samples prepared at R.T. and heated at $300{ }^{\circ} \mathrm{C}$ were light blue powder. By heating at $500{ }^{\circ} \mathrm{C}$, the color of phosphate became darker. Sample heated at $700{ }^{\circ} \mathrm{C}$ had a distinct difference from other samples. The color of phosphate pigment changed to deep green by heating at $700{ }^{\circ} \mathrm{C}$. Fig. 3 shows the UV-vis reflectance spectra of the samples heated at various temperatures. The sample heated at the highest temperature showed the lower reflectance at

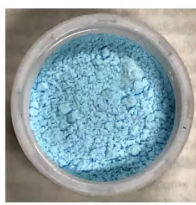

a)

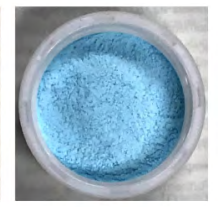

b)

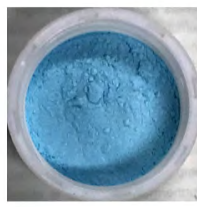

c)

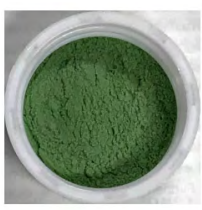

d)
Figure 2: Photographs of samples $(\mathrm{Cu} / \mathrm{Al}=1 / 6)$ heated at various temperatures (pH 5): a) R.T.; b) $300{ }^{\circ} \mathrm{C}$; c) $500{ }^{\circ} \mathrm{C}$; and d) $700{ }^{\circ} \mathrm{C}$. [Figura 2: Fotografias de amostras (Cu/Al=1/6) aquecidas a várias temperaturas ( $\mathrm{pH} \mathrm{5}$ ): a) temperatura ambiente; b) $300{ }^{\circ} \mathrm{C}$; c) $500{ }^{\circ} \mathrm{C}$; e d) $\left.700{ }^{\circ} \mathrm{C}.\right]$ 


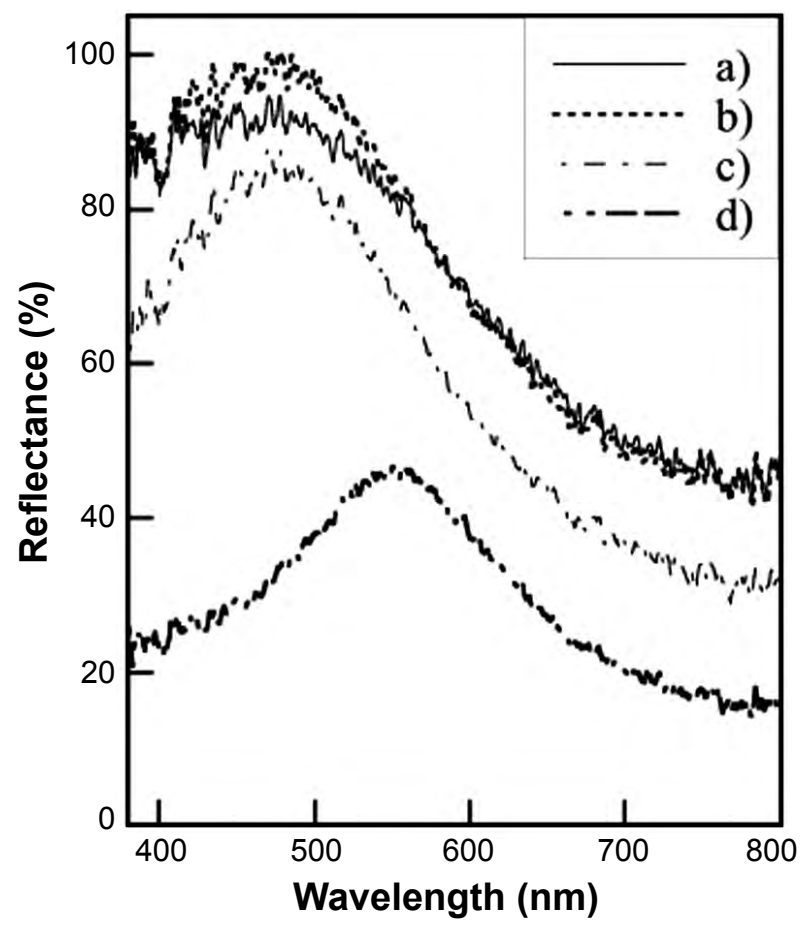

Figure 3: UV-vis reflectance spectra of samples $(\mathrm{Cu} / \mathrm{Al}=1 / 6)$ heated at various temperatures (pH 5): a) R.T.; b) $300{ }^{\circ} \mathrm{C}$; c) $500{ }^{\circ} \mathrm{C}$; and d) $700{ }^{\circ} \mathrm{C}$.

[Figura 3: Espectros de reflectância UV-Vis de amostras (Cu/ $\mathrm{Al}=1 / 6)$ aquecidas a várias temperaturas ( $\mathrm{pH} \mathrm{5):} \mathrm{a)} \mathrm{temperatura}$ ambiente; b) $300{ }^{\circ} \mathrm{C}$; c) $500{ }^{\circ} \mathrm{C}$; e d) $700{ }^{\circ} \mathrm{C}$.]

Table I - L*a*b* values of samples $(\mathrm{Cu} / \mathrm{Al}=1 / 6)$ heated at various temperatures.

[Tabela I - Valores $L^{*} a^{*} b^{*}$ de amostras (Cu/Al=1/6) aquecidas a várias temperaturas.]

\begin{tabular}{ccccc}
\hline Temp. $\left({ }^{\circ} \mathrm{C}\right)$ & $\mathrm{pH}$ & $\mathrm{L}^{*}$ & $\mathrm{a}^{*}$ & $\mathrm{~b}^{*}$ \\
\hline R.T. & 5 & 82.09 & -10.66 & -9.13 \\
300 & 5 & 88.93 & -13.82 & -13.78 \\
500 & 5 & 79.71 & -15.43 & -13.65 \\
700 & 5 & 66.89 & -12.19 & 13.34 \\
R.T. & 7 & 80.72 & -10.18 & -8.82 \\
300 & 7 & 86.53 & -12.84 & -12.02 \\
500 & 7 & 73.01 & -14.01 & -10.45 \\
700 & 7 & 58.66 & -4.81 & 13.88 \\
R.T. & 9 & 89.14 & -13.00 & -7.83 \\
300 & 9 & 80.75 & -12.84 & -1.53 \\
500 & 9 & 73.74 & -14.01 & -8.25 \\
700 & 9 & 44.72 & -2.21 & 3.35 \\
\hline
\end{tabular}

the visible range. The peak shifted from 470 to $550 \mathrm{~nm}$ by heating at $700{ }^{\circ} \mathrm{C}$. These results were corresponding with the color change, from light blue to dark green. Table I shows the $\mathrm{L}^{*} \mathrm{a} * \mathrm{~b} *$ values of the sample powders prepared under various conditions. Because the $b^{*}$ value had a distinct

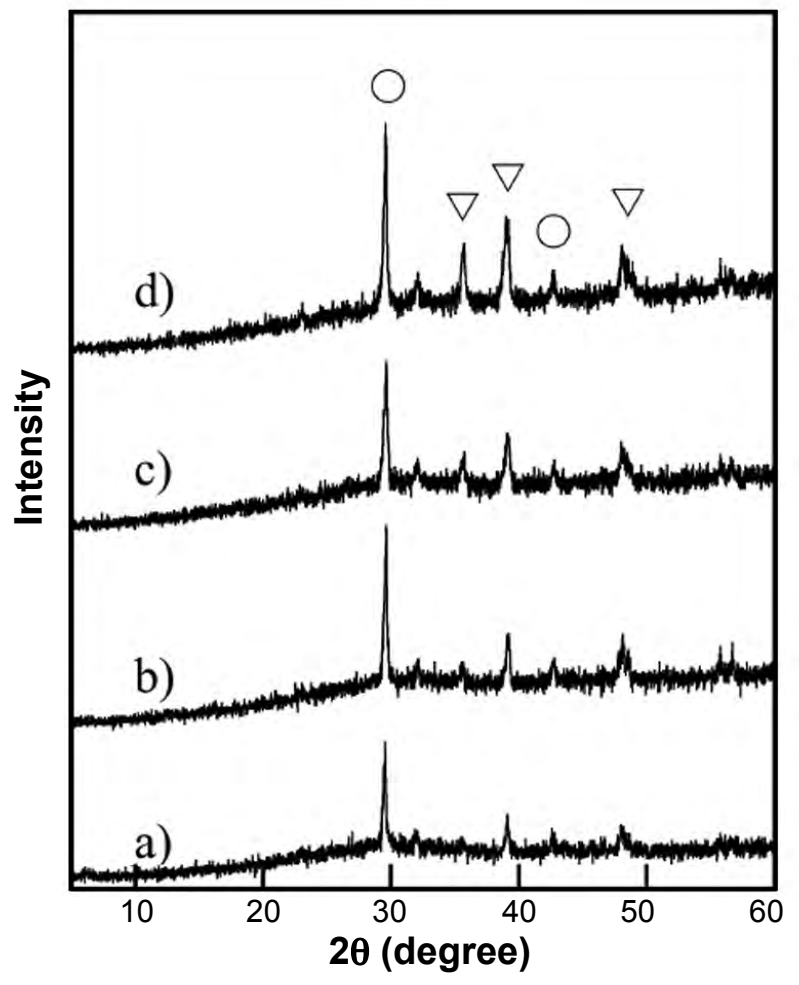

Figure 4: XRD patterns of samples prepared at various $\mathrm{Cu}$ / Al ratios $\left(300{ }^{\circ} \mathrm{C}\right)$ : a) $1 / 6$; b) $1 / 3$; c) $1 / 2$; and d) $2 / 3$. $\bigcirc-$ $\mathrm{CuAl}_{6}\left(\mathrm{PO}_{4}\right)_{4}(\mathrm{OH})_{8} \cdot 4 \mathrm{H}_{2} \mathrm{O} ; \nabla-\mathrm{CuO}$.

[Figura 4: Padrões de DRX de amostras preparadas com várias razões $\mathrm{Cu} / \mathrm{Al}\left(300{ }^{\circ} \mathrm{C}\right):$ a) $1 / 6$; b) $1 / 3$; c) $1 / 2$; e d) $2 / 3$.]

Table II - L*a*b* values of samples prepared at various conditions ( $\mathrm{pH} 7$ ).

[Tabela II - Valores $L^{*} a^{*} b^{*}$ de amostras preparadas em várias condições ( $\mathrm{pH} 7)$.]

\begin{tabular}{ccccc}
\hline $\mathrm{Cu} / \mathrm{Al}$ & Temp. $\left({ }^{\circ} \mathrm{C}\right)$ & $\mathrm{L}^{*}$ & $\mathrm{a}^{*}$ & $\mathrm{~b}^{*}$ \\
\hline $1 / 6$ & 300 & 86.53 & -12.84 & -12.02 \\
$1 / 3$ & 300 & 76.14 & -17.45 & -9.14 \\
$1 / 2$ & 300 & 64.47 & -10.53 & -5.48 \\
$2 / 3$ & 300 & 51.89 & -7.17 & -3.67 \\
$1 / 6$ & 500 & 73.01 & -14.01 & -10.45 \\
$1 / 3$ & 500 & 66.77 & -16.72 & -4.50 \\
$1 / 2$ & 500 & 38.05 & -0.17 & -1.80 \\
$2 / 3$ & 500 & 42.39 & -3.28 & -3.50 \\
\hline
\end{tabular}

change by heating at $700{ }^{\circ} \mathrm{C}$, the color of powders changed from light blue to green (from negative to positive). By heating at higher temperature, sample powder became dark (low $\mathrm{L}^{*}$ value). Samples prepared at $\mathrm{pH} 7$ and 9 indicated weak green hue at $700{ }^{\circ} \mathrm{C}\left(\mathrm{a}^{*}\right.$ value).

Other compositions: to obtain a novel blue pigment, the compositions related to $\mathrm{CuAl}_{6}\left(\mathrm{PO}_{4}\right)_{4}(\mathrm{OH})_{8} \cdot 4 \mathrm{H}_{2} \mathrm{O}$ were also estimated. Because we prepared the materials at $\mathrm{Cu} / \mathrm{Al}=1 / 3$, $1 / 2$, and $2 / 3$ in previous paper [19], the compositions with the same $\mathrm{Cu} / \mathrm{Al}$ ratios were studied. Fig. 4 shows the XRD patterns of the samples prepared at various $\mathrm{Cu} / \mathrm{Al}$ ratios. All 
samples had the peaks of $\mathrm{CuAl}_{6}\left(\mathrm{PO}_{4}\right)_{4}(\mathrm{OH})_{8} \cdot 4 \mathrm{H}_{2} \mathrm{O}$ and $\mathrm{CuO}$. The samples prepared at $\mathrm{Cu} / \mathrm{Al}=2 / 3$ had strong peaks of copper oxide. Therefore, turquoise imitating compound was easy to form under copper-rich condition. Table II shows the $\mathrm{L}^{*} \mathrm{a} * \mathrm{~b} *$ values of the samples prepared at various $\mathrm{Cu} / \mathrm{Al}$ ratios. Because samples prepared with high copper ratio became dark powder (low $\mathrm{L}^{*}$ value), the $\mathrm{a}^{*}$ and $\mathrm{b}^{*}$ values of these materials approached zero. Therefore, to obtain light blue and deep green phosphate pigments, the low copper ratio was suitable.

\section{CONCLUSIONS}

The novel phosphate pigments imitating turquoise were prepared by mixing copper nitrate solution, aluminum nitrate solution, phosphoric acid, and sodium hydroxide solution. The samples heated at low temperature $\left(\leq 500{ }^{\circ} \mathrm{C}\right)$ were light blue powder. By heating at $700{ }^{\circ} \mathrm{C}$, the color of materials changed to deep green. Samples with high copper ratio indicated lower $L^{*}$ value and small $a^{*}$ and $b^{*}$ values. The low copper ratio was suitable to obtain light blue and deep green phosphate pigments.

\section{REFERENCES}

[1] G. Agresti, P. Baraldi, C. Pelosi, U. Santamaria, Color Res. Appl. 41, 3 (2016) 226.

[2] M. Vermeulen, S. Saverwyns, A. Coudray, K. Janssens, J. Sanyova, Dyes Pigm. 149 (2018) 290.

[3] A. Amat, C. Millani, S. Fantacci, RSC Adv. 6 (2016) 36336.

[4] Z. Tao, W. Zhang, Y. Huang, D. Wei, H.J. Seo, Solid State Sci. 34 (2014) 78.

[5] M. Radepont, Y. Conquinot, K. Janssens, J.-J. Ezrati, M.
Cotte, J. Anal. At. Spectrom. 30 (2015) 599.

[6] F. Rosi, C. Grazia, F. Gabrieli, A. Romani, M. Paolantoni, R. Vivani, B.G. Brunetti, P. Colomban, C. Miliani, Microchem. J. 124 (2016) 856.

[7] M. Li, J. Wand, Q. Ma, J. Cult. Herit. 16, 4 (2015) 575.

[8] S. Jiang, L. Peng, R. Guo, D. Miao, S. Shang, J. Xu, A. Li, Ceram. Int. 42, 16 (2016) 19386.

[9] C. Migurei, J.V. Pinto, M. Clarke, M.J. Melo, Dyes Pigm. 102 (2014) 210.

[10] M. Ohashi, K. Kusumoto, T. Sugiyama, K. Kato, J. Ceram. Soc. Jpn. 124, 9 (2016) 959.

[11] H. Onoda, K. Sugimoto, J. Asian Ceram. Soc. 5, 2 (2017) 123.

[12] H. Onoda, S. Fujikado, Cerâmica 64, 372 (2018) 623.

[13] I.O. Ali, T.M. Salam, M.S. Thabet, K.S. El-Nasser, A.M. Hassan, Mater. Chem. Phys. 140 (2013) 81.

[14] M. Gaudon, L.C. Robertson, E. Lataste, M. Duttine, M. Ménétrier, A. Demourgues, Ceram. Int. 40 (2014) 5201.

[15] E.M. Angelin, M. Bacci, G. Bartolozzi, E. Cantisani, M. Picollo, Spectrochim. Acta 173 (2017) 510.

[16] S. Jose, M.L. Reddy, Dyes Pigm. 98 (2013) 540.

[17] J. Cejka, J. Sejkora, I. Macek, R. Malíková, L. Wang, R. Scholz, Y. Xi, R.L. Frost, Spectrochim. Acta 149 (2015) 173.

[18] G. Othmane, S. Hull, M. Fayek, O. Rouxel, M.L. Geagea, T.K. Kyser, Chem. Geol. 395 (2015) 41.

[19] H. Onoda, R. Sasaki, Mater. Res. Innov. 23, 5 (2019) 266.

[20] L.S. Kumari, P.P. Rao, A.N.P. Radhakrishnan, V. James, S. Sameera, P. Koshy, Sol. Energy Mater. Sol. Cells 112 (2013) 134.

[21] http://rruff.info/Turquoise/R050554.

[22] H. Onoda, T. Funamoto, J. Fluoresc. 25, 2 (2015) 247.

(Rec. 12/06/2019, Rev. 16/07/2019, Ac. 17/07/2019) 